\title{
PENGARUH PERKEMBANGAN BANK UMUM SYARIAH TERHADAP PERTUMBUHAN EKONOMI INDONESIA PERIODE 2010-20151)
}

\author{
Firmansyah Putra \\ Mahasiswa Program Studi S1 Ekonomi Islam-Fakultas Ekonomi dan Bisnis-Universitas Airlangga \\ Email: firmansyah.putra12@feb.unair.ac.id \\ Muhammad Nafik H.R \\ Departemen Ekonomi Syariah-Fakultas Ekonomi dan Bisnis-Universitas Airlangga \\ Email: muhammad-n-h-r@feb.unair.ac.id
}

\begin{abstract}
:
The study aims to examines the influence of Islamic banks on economic growth in Indonesia during the period 2010-2015. Secondary data that were used in this research were in the form of monthly time series and cross-section data during the year 2010-2015. The data were obtained based on monthly statistical banking report from Bank Indonesia (BI) and monthly statistical reports of the Monthly Industrial Production Index in the Large and Medium scale from Central Bureau of Statistics (BPS) of Indonesia and also annual report from each islamic banks that conclude in this observation. Total assets, and total financing as variables that are representing the Islamic bank. GDP (Gross Domestic Product) is the variable that representing economic growth. By using Multiple Regression Analysis, the result shows that generally, Islamic banking affects economic growth in Indonesia.
\end{abstract}

Keywords : Islamic Banks, Gross Domestic Bruto Banking Sector, Economic Growth

\section{Pendahuluan}

\section{Latar Belakang}

Bank dapat dikatakan sebagai nadi dari perekonomian. Semakin tinggi kemampuan bank dalam menyalurkan pembiayaan, maka akan semakin tinggi pula usaha-usaha baru yang didirikan oleh masyarakat. Jangka panjangnya masyarakat akan mampu menghidupi diri mereka sendiri tanpa ada ketergantungan dari pihak lain. Oleh karena itu perkembangan bank menjadi tolak ukur keberhasilan suatu negara. Semakin besar peran perbankan dalam mengendalikan negara maka semakin maju pula negara itu.

Apabila sektor keuangan berkembang dengan baik, maka semakin banyak pula sumber pembiayaan yang dapat
Landasan-landasan perbankan syariah bersumber dari fitrah manusia yang berinteraksi dengan porsinya masingmasing hingga terbentuklah sebuah mekanisme ekonomi yang khas dengan dasar-dasar nilai llahiyah. (Karim, 2004)

Indonesia merupakan negara dengan penduduk Muslim terbesar di dunia. Menurut Badan Pusat Statistik, penduduk Indonesia pada saat sensus penduduk 2010 berjumlah 237 juta jiwa dan 87,18\% dari penduduk Indonesia beragama Islam, yaitu sekitar 207,2 juta jiwa. Banyaknya jumlah penduduk Muslim Indonesia membuat Indonesia memiliki potensi yang signifikan untuk berkontribusi bagi kemajuan perbankan syariah. (Soemitra, 2009) 
Putra, et al/Jurnal Ekonomi Syariah Teori dan Terapan Vol. 4 No. 12 Desember 2017: 952-967; PENGARUH PERKEMBANGAN BANK UMUM SYARIAH TERHADAP PERTUMBUHAN EKONOMI INDONESIA PERIODE 2010-2015

Faktor yang terpenting dalam ekonomi islam adalah manusia Islami. Qardhawi menjelaskan bahwa kaidah pertama dalam membangun ekonomi islam adalah menghargai nilai harta benda dan kedudukannya dalam kehidupan, sehingga kekayaan itu atau harta benda merupakan sarana manusia untuk bertakwa kepadaNya. (Banoon dan Malik,2007)

Pada tahun 1992 Indonesia mulai memperkenalkan sistem keuangan dan perbankan ganda karena bank boleh beroperasi dengan prinsip bagi hasil dengan landasan hukum Undang-Undang Perbankan No.7 Tahun 1992, dimana bank syariah pertama beroperasi pada tahun itu adalah Bank Muamalat Indonesia.

Bersamaan dengan perjalanan waktu, penerapan sistem keuangan dan perbankan ganda mulai terarah, khususnya setelah disahkannya UndangUndang Perbankan yang baru No.10 Tahun 1998. Sehingga dengan demikian, pada tahun 1992 merupakan awal dari perjalanan ekonomi syariah secara legal di Indonesia dan upaya yang dilakukan ini adalah sebagai salah satu bentuk untuk aplikasi internalisasi nilai ajaran ke-Islaman kedalam aspek kehidupan, khususnya dalam kegiatan berekonomi.

Penerapan sistem keuangan dan perbankan ganda mulai terarah semenjak dikeluarkannya Undang-Undang Perbankan yang baru No.10 Tahun 1998, sehingga setelah itu bermunculan lembaga keuangan syariah yang beroperasi berdampingan dengan lembaga keuangan konvensional. Menurut Peraturan Bank Indonesia (PBI) No.2/8/PBI/2004, bank syariah adalah bank umum yang melakukan kegiatan usaha berdasarkan prinsip syariat islam, termasuk unit usaha syariah dan kantor cabang bank asing yang melakukan kegiatan usaha berdasarkan prinsip syariat islam.

Komitmen pemerintah dalam usaha pengembangan perbankan syariah baru mulai terasa sejak tahun 1998, yang memberikan kesempatan yang luas kepada bank syariah untuk berkembang. Tahun berikutnya, Bank Indonesia diberikan amanah untuk mengembangkan perbankan di Indonesia. Selain menganut strategi market driven dan fair treatment, pengembangan perbankan syariah di Indonesia dilakukan dengan strategi pengembangan bertahap yang berkesinambungan (gradual and sustainable approach) yang sesuai prinsip syariah (compliance to Sharia Principles). (Karim, 2004)

Pangsa pasar Perbankan Syariah terhadap Industri Perbankan Nasional terus-menerus mengalami kenaikan. Hal ni menunjukkan bahwa peran bank syariah semakin besar dalam perekonomian nasional. Lalu aset marketshare untuk Aset mengalami peningkatan sejak 2010-2015. Posisi terakhir sebesar $4.97 \%$ (2015), dimana naik hampir $2 x$ dibanding lima tahun silam (2010). Demikian pula dengan kelembagaan, pada tahun 2015 ini bertambah lagi satu Bank Umum Syariah 
Putra, et al/Jurnal Ekonomi Syariah Teori dan Terapan Vol. 4 No. 12 Desember 2017: 952-967; PENGARUH PERKEMBANGAN BANK UMUM SYARIAH TERHADAP PERTUMBUHAN EKONOMI INDONESIA PERIODE 2010-2015

yaitu BTPN (Bank Tabungan Pensiunan Nasional) Syariah.(Statistik Perbankan Syariah, 2010-2015

Keberadaan bank syariah diharapkan dapat mendorong perekonomian suatu negara. Tujuan dan fungsi perbankan syariah dalam perekonomian adalah: kemakmuran ekonomi yang meluas, tingkat kerja penuh dan tingkat pertumbuhan ekonomi yang optimum, keadilan sosial ekonomi dan distribusi pendapatan, serta kekayaan yang merata, stabilitas nilai vang, mobilisasi dan investasi tabungan yang menjamin adanya pengembalian yang adil, serta pelayanan yang efektif. (Setiawan,2006)

Bilamana dilihat pada total aset pada 2010 masih sangat kecil padahal sudah berdiri 11 bank umum syariah. Pada 2010 sendiri total aset bank umum syariah mencapai Rp.77.9 triliun rupiah. Namun perlahan tahun-tahun selanjutnya perbankan syariah meningkat signifikan, seperti pada tahun 2011 yang totalnya Rp.113,8 triliun rupiah, selanjutnya pada tahun 2012 yang mencapai Rp.154,4 triliun rupiah. Lalu pada 2013 mencapai Rp.218 triliun rupiah. Dan tahun 2014 dan 2015 yang masing-masing mencapai Rp.250,7 triliun rupiah dan Rp.274,3 triliun rupiah.(Statistik Perbankan Syariah, 20102015)

$\begin{array}{lccr}\text { Begitu pula dengan } & \text { total } \\ \text { pembiayaan, pada tahun } & 2010 \\ \text { pembiayaan bank } & \text { umum } & \text { syariah } \\ \text { mencapai } & \text { Rp. } 56,7 & \text { triliun } & \text { rupiah. }\end{array}$
Selanjutnya pada tahun 2011 mencapai
Rp.84,9 triliun rupiah. Lalu pada tahun 2012 mencapai Rp.121,1 triliun rupiah. Lalu pada tahun 2013 meningkat dengan jumlah Rp.169,7 triliun rupiah. Begitu pula tahun 2014 dan 2015 yang meningkat menjadi Rp.191,3 triliun rupiah dan Rp.204, 1 triliun rupiah.(Statistik Perbankan Syariah, 2010-2015)

Berdasarkan uraian latar belakang yang telah dijelaskan di atas, maka peneliti merumuskan masalah penelitian yang diangkat dalam penelitian ini sebagai berikut, yaitu Bagaimana pengaruh total aset dan total pembiayaan bank umum syariah baik secara simultan maupun secara parsial terhadap produk domestik bruto sektor perbankan nasional periode 2010-2015.

\section{LANDASAN TEORI}

Menurut Undang-Undang Republik Indonesia no.21 tahun 2008 Perbankan Syariah adalah segala sesuatu yang menyangkut tentang Bank Syariah dan Unit Usaha Syariah, mencakup kelembagaan, kegiatan usaha, serta cara dan proses dalam melaksanakan kegiatan usahanya.

Perbankan syariah atau Perbankan Islam adalah suatu sistem perbankan yang dikembangkan berdasarkan syariah (hukum) Islam. Usaha pembentukan sistem ini didasari oleh larangan dalam agama Islam untuk memungut maupun meminjam dengan bunga atau yang disebut dengan riba serta larangan investasi untuk usaha-usaha yang dikategorikan haram (misal: usaha yang berkaitan

dengan

produksi 
Putra, et al/Jurnal Ekonomi Syariah Teori dan Terapan Vol. 4 No. 12 Desember 2017: 952-967; PENGARUH PERKEMBANGAN BANK UMUM SYARIAH TERHADAP PERTUMBUHAN EKONOMI INDONESIA PERIODE 2010-2015

makanan/minuman haram, usaha media yang tidak Islami dll), dimana hal ini tidak dapat dijamin oleh sistem perbankan konvensional.

Antonio dan Perwataadmadja (1992: 27) membedakan bank syariah menjadi dua macam, yaitu bank Islam dan bank yang beroperasi sesuai dengan prinsip syariah islam. Bank Islam adalah bank yang beroperasi dengan prinsip syariah Islam dan bank yang tata cara operasionalnya mengacu pada ketentuan Al-Quran dan Hadist. Sementara itu, bank yang beroperasi sesuai prinsip syariah Islam adalah bank yang dalam beroperasinya mengikuti ketentuan-ketentuan syariah Islam, khususnya yang menyangkut tata cara bermuamalah secara Islam.

Secara garis besar, menurut Syafi'i Antonio (2001:83) kegiatan operasional bank umum syariah didasarkan kepada 5 aqad. Bersumber dari 5 aqad inilah dapat ditentukan produk-produk lembaga keuangan bank syariah. 5 aqad tersebut adalah al-wadiah, syirkah, at-tijarah, alijarah, al-ajr.

Menurut Boediono (1999:81), pertumbuhan ekonomi dapat didefenisikan sebagai penjelasan mengenai faktor-faktor apa yang menentukan kenaikan output perkapita dalam jangka panjang dan penjelasan bagaimana faktor-faktor tersebut sehingga terjadi proses pertumbuhan.

Pertumbuhan ekonomi dalam Sukirno (2006:423) sebagai suatu ukuran kuantitatif yang menggambarkan perkembangan suatu perekonomian dalam suatu tahun tertentu apabila dibandingkan dengan tahun sebelumnya. Pertumbuhan ekonomi dapat diketahui dengan membandingkan PDB pada satu tahun tertentu dengan PDB tahun sebelumnya.

Pertumbuhan ekonomi dapat dinilai sebagai dampak kebijaksanaan pemerintah, khususnya dalam bidang ekonomi. Pertumbuhan ekonomi merupakan laju pertumbuhan yang dibentuk dari berbagai macam sektorekonomi yang secara tidak langsung menggambarkan tingkat pertumbuhan yang terjadi dan sebagai indikator penting bagi daerah untuk mengevaluasi keberhasilan pembangunan (Sirojuzilam, 2008:16).

\section{Hipotesis dan Model Analisis}

Berdasarkan latar belakang, rumusan masalah dan landasan teori yang telah dipaparkan, maka dalam penelitian ini dapat dirumuskan hipotesis, yaitu :

$\mathrm{HI}$ : Terdapat pengaruh yang signifikan baik secara simultan dan parsial antara total aset bank umum syariah dan total pembiayaan bank umum syariah terhadap produk domestik bruto sektor perbankan tahun 2010-2015.

\section{METODOLOGI PENELITIAN}

\section{Pendekatan Penelitian}

Pendekatan yang digunakan dalam penelitian ini adalah pendekatan kuantitatif. Adapun variabel yang digunakan dalam penelitian ini meliputi variabel bebas yang terdiri dari 2 variabel, 
Putra, et al/Jurnal Ekonomi Syariah Teori dan Terapan Vol. 4 No. 12 Desember 2017: 952-967; PENGARUH PERKEMBANGAN BANK UMUM SYARIAH TERHADAP PERTUMBUHAN EKONOMI INDONESIA PERIODE 2010-2015

yaitu total aset bank umum syariah, dan total pembiayaan bank umum syariah. Sedangkan variabel terikat dalam penelitian ini adalah produk domestik bruto sektor perbankan

\section{Definisi Operasional}

1. Total Aset Bank Umum Syariah

Total Aset yang didapatkan dari segala sumber pemasukan perbankan syariah. Total aset perbankan syariah yang mempengaruhi perubahan produk domestik bruto pada tahun $n$ adalah jumlah total aset perbankan syariah pada tahun $\mathrm{n}$. Variabel total aset didefinisikan sebagai variabel bebas dan diperoleh dari laporan tahunan masing-masing bank umum syariah pada periode 2010-2015.

2. Total Pembiayaan bank Umum Syariah

Total pembiayaan merupakan produk perbankan syariah berupa penyaluran dana kepada masyarakat. Total pembiayaan perbankan syariah yang mempengaruhi perubahan produk domestik bruto pada tahun $n$ adalah jumlah total pembiayaan perbankan syariah pada tahun $\mathrm{n}$. Variabel total pembiayaan didefinisikan sebagai variabel bebas dan diperoleh dari laporan tahunan masing-masing bank umum syariah pada periode 20102015
3. Produk Domestik Bruto sektor perbankan

PDB berasal dari perhitungan nilai tambah barang dan jasa tersebut yang dihitung menggunakan harga yang berlaku pada satu tahun tertentu sebagai tahun dasar. PDB ini digunakan untuk mengetahui pertumbuhan ekonomi dari tahun ke tahun. Variabel produk domestik bruto didefinisikan sebagai variabel terikat dan diperoleh dari laporan tahunan Badan Pusat Statistik (BPS) pada periode 2010-2015.

\section{Jenis dan Sumber Data}

Jenis data dalam penelitian ini merupakan data sekunder. Data time series yang digunakan merupakan data tahunan selama enam tahun penelitian, yaitu tahun 2010-2015.

Data cross section yang digunakan merupakan data sampel Bank Umum Syariah yang terdiri dari BCA Syariah, BJB Syariah, BNI Syariah, BRI Syariah, Bukopin Syariah, Mandiri Syariah, Maybank Syariah, Mega Syariah, Muamalat, Panin Syariah, Victoria Syariah yang didapat dari laporan tahunan masing-masing bank.

\section{Prosedur Pengumpulan Data}

Prosedur pengumpulan data dilaksankan dengan metode dokumenter, artinya data yang diperlukan dalam penelitian ini adalah data sekunder yang telah didokumentasi oleh instansi atau dinas terkait (OJK, BPS, dan BI). Semua data yang diperlukan yaitu produk domestik bruto sektor perbankan, total 
Putra, et al/Jurnal Ekonomi Syariah Teori dan Terapan Vol. 4 No. 12 Desember 2017: 952-967; PENGARUH PERKEMBANGAN BANK UMUM SYARIAH TERHADAP PERTUMBUHAN EKONOMI INDONESIA PERIODE 2010-2015

aset perbankan syariah, dan total pembiayaan perbankan syariah.

Data-data tersebut didokumentasikan dari sumber-sumber yang telah disebutkan, kemudian semua data yang telah diperoleh tersebut diolah dan dianalisis dengan teknik/metode analisis kuantitatif, yaitu menggunakan model data panel berdasarkan pada literaturliteratur yag mendukung.

\section{Populasi dan Sampel}

Populasi dalam penelitian ini adalah seluruh Bank Umum Syariah (BUS) yagn beroperasi di Indonesia pada tahun 20102015 yaitu berjumlah 11 BUS. Kriteria dari sampel adalah :

- Bank Umum Syariah telah beroperasi selama 5 tahun

- Mengeluarkan laporan tahunan selama 5 tahun terakhir

- Periode Penelitian 2010-2015

Maka dari itu ditetapkan bahwa yang menjadi sampel dari penelitian ini adalah 11 bank umum syariah.

\section{Teknik Analisis}

Penelitian ini menggunakan teknik analisis regresi berganda yang menggunakan data panel yang mengandung variabel bebas dan variabel terikat. Setelah menentukan variabel-variabel yang digunakan sebelumnya, maka akan dilakukan pengujian secara kuantitatif. Metode kuantitatif merupakan gabungan pengujian teori ekonomi, statistik, dan model matematik.

\section{Model Regresi Data Panel}

Persamaan model regresi adalah sebagai berikut :

$Y=\beta 0+\beta 1 \times 1+\beta 2 \times 2+e$

dimana :

$$
\begin{array}{ll}
Y & =\text { Produk Domestik Bruto } \\
\beta 0 & =\text { konstanta } \\
\beta 1 \ldots \beta 3 & =\text { koefisien regresi masing-masing } \\
& \text { variabel dependen } \\
\mathrm{X} 1 & =\text { TABS } \\
\mathrm{X} 2 & =\text { PBS } \\
\mathrm{e} & =\text { tingkat kesalahan }
\end{array}
$$

\section{Uji Syarat Regresi}

\section{Uji Normalitas}

Bertujuan untuk menguji apakah dalam sebuah model regresi, variabel dependen, variabel independen atau keduanya mempunyai distribusi normal ataukah tidak. Model regresi yang baik adalah distribusi data normal atau mendekati normal. (Gujarati, 2007;64).

\section{Uji Linieritas}

Digunakan untuk melihat apakah spesifikasi model yang digunakan sudah benar atau tidak. Ada beberapa metode yang dilakukan untuk melakukan pengujian linearitas, tetapi dalam penelitian untuk melakukan pengujian linearitas menggunakan metode Langrange Multipler yang merupakan uji alternative dari Ramsey test

Penghitungan nya adalah sebagai berikut:

LMhitung $=\frac{n T}{2(T-1)}\left[\frac{\sum_{i=1}^{n}\left(\sum_{t=1}^{T} e\right) x^{2}}{\sum_{i=1}^{n} \sum_{t=1}^{T} e^{2}}-1\right] x^{2}$

Dimana:

$n=$ jumlah perusahaan

$T=$ jumlah periode

$\Sigma e^{2}=$ jumlah rata-rata kuadrat residual 
Putra, et al/Jurnal Ekonomi Syariah Teori dan Terapan Vol. 4 No. 12 Desember 2017: 952-967; PENGARUH PERKEMBANGAN BANK UMUM SYARIAH TERHADAP PERTUMBUHAN EKONOMI INDONESIA PERIODE 2010-2015

$\Sigma e^{2}=$ jumlah residual kuadrat

\section{Uji Chow}

Penentuan model terbaik antara OLS pooled dan Model Efek Tetap (FEM) adalah menggunakan Uji Chow.

\section{Uji Hausment}

Sedangkan untuk memilih antara Model Efek Tetap (Fixed Effect Model) atau Model Efek Random (Random Effect Model) menggunakan Uji Hausman.

\section{Uji Langrange Multiplier}

Dilakukan untuk membandingkan/memilih model mana yang terbaik antara Fixed Effect atau Random Effect.

\section{Uji Hipotesis}

Maka hipotesis dapat dirumuskan dapat sebagai berikut :

Ho: Tidak terdapat hubungan pengaruh yang signifikan secara simultan dan parsial antara variabel bebas (independent) yaitu total aset bank umum syariah dan total pembiayaan bank umum syariahterhadap variabel terikat (dependent) produk domestik bruto sektor perbankan tahun 2010-2015.

$\mathrm{Hi}$ : terdapat hubungan pengaruh yang signifikan secara simultan dan parsial antara variabel bebas (independent) yaitu total aset bank umum syariah dan total pembiayaan bank umum syariahterhadap variabel terikat (dependent) produk domestik bruto sektor perbankan tahun 2010-2015.

\section{Uji Hipotesis Secara Simultan}

$\mathrm{H}_{0}=$ semua variabel bebas (independent variable) pada model secara bersama-sama tidak berpengaruh terhadap vriabel terikat (dependent variable).

$\mathrm{H}_{1}=$ setidaknya ada satu variabel bebas (independent variable) pada model yang mempengaruhi variabel terikat (dependent variable).

\section{Uji Hipotesis Secara Parsial}

Pengujian $†$ statistik digunakan untuk menguji pengaruh parsial dari variabel bebas terhadap variabel terikat. Pengujian ini dilakukan dengan menetapkan :

Hipotesis pertama

$\mathrm{H}_{0}: \beta_{2}=0 \quad$ (variabel $\mathrm{X}_{1}$ tidak mempengaruhi variabel $Y$ )

$H_{0}: \beta_{2} \neq 0 \quad$ (Variabel $X_{1}$ mempengaruhi variabel $\mathrm{Y}$ )

Hipotesis kedua

$\mathrm{H}_{0}: \beta_{3}=0 \quad$ (variabel $\mathrm{X}_{2}$ tidak mempengaruhi variabel $Y$ )

$\mathrm{H}_{0}: \beta_{3} \neq 0 \quad$ (Variabel $\mathrm{X}_{2}$ mempengaruhi variabel $\mathrm{Y}$ )

\section{Uji $\mathbf{R}^{2}$ (R-squared)}

Fungsi uji $R^{2}$ adalah untuk menentukan apakah variasi dari variabel bebas yang ada dalam persamaan estimasi telah menjelaskan variasi dari variabel terikatnya dengan baik. Nilai koefisien $\mathrm{R}^{2}$ berkisar 0 hingga 1.

Suatu model regresi apabila $R^{2}$ mencapai angka 1, maka variasi dari variabel bebasnya dapat menerangkan atau menjelaskan variasi dari variabel terikatnya dengan sempurna, sebaliknya 
Putra, et al/Jurnal Ekonomi Syariah Teori dan Terapan Vol. 4 No. 12 Desember 2017: 952-967; PENGARUH PERKEMBANGAN BANK UMUM SYARIAH TERHADAP PERTUMBUHAN EKONOMI INDONESIA PERIODE 2010-2015

apabila $R^{2}$ mencapai angka 0 , maka ini berarti variasi dari variabel bebasnya lemah dalam menerangkan variasi variabel terikatnya.

\section{HASIL DAN PEMBAHASAN}

Salah satu sistem perbankan di Indonesia, yaitu perbankan syariah mempunyai potensi yang besar untuk terus berkembang. Meskipun pangsa pasar nya saat ini masih dibawah bank konvensional, namun diyakini perbankan syariah dapat melebihi pangsa pasar perbankan konvensional. Seperti contohnya pada tahun 2012, pada saat booming perbankan syariah tahun 2012 , itu pertumbuhan kreditnya bisa 25\%-27\% dan perbankan syariahnya bisa sedikit di atas itu.

Masalah yang terjadi pada semua bank umum syariah yaitu masih kecilnya kapasitas perbankan syariah. Rata-rata perbankan syariah di Indonesia hanya memiliki modal 1 Triliun-5 Triliun. Kapasitas bank syariah yang besar dapat mendorong semakin besarnya kegiatan usaha yang dapat dilakukan. Maka dari itu OJK mengharapkan dukungan dari pemerintah agar bank-bank syariah di Indonesia dapat menjadi lebih besar dari sebelumnya.

Modal yang semakin besar otomatis akan membuat bank-bank syariah semakin leluasa dalam mengelola kevangan mereka. Berbagai inovasi produk baru dapat dimunculkan sehingga masyarakat akan semakin tertarik untuk menginvestasikan dananya di perbankan syariah. Begitu pula dengan pembiayaan, dengan meningkatnya modal maka perbankan syariah akan semakin leluasa dalam menjalankan fungsinya yaitu sebagai intermediasi keuangan.

Sehingga akan semakin banyak masyarakat yang terbantu dengan adanya pembiayaan dari perbankan syariah, semakin meningkatkanya pembiayaan berarti akan semakin tinggi pula bagi hasil yang diterima perbankan syariah tersebut dan berdampak pula lagilagi pada meningkatnya total aset dan total pembiayaan perbankan syariah.

Meningkatnya modal bank-bank syariah juga dapat berarti dapat membuka kantor cabang baru, mengembangkan infrastruktur. Produk yang saat ini ada di perbankan syariah dinilai tidak variatif dan tidak sesuai kebutuhan masyarakat, dimana fitur bank syariah tidak selengkap yang ada di bank konvensional. Marketshare perbankan syariah di Indonesia pun masih sangat kecil jika dibaningkan di Malaysia yang sudah mencapai $20 \%$ dikarenakan pemerintah Malaysia menempatkan vang APBN di bank syariah. Ini yang menyebabkan bank syariah di Malaysia berkembang pesat dan terintegrasi.

Tantangan yang harus dihadapi kedepannya adalah akan adanya Masyakarat Ekonomi Asean (MEA) dimana akan memungkinkan perbankanperbankan syariah di Asean untuk membuka cabangnya di Indonesia. Semakin sengitnya persaingan ditambah masih adanya keterbatasan modal, kekurangan tenaga kerja profesional, dan 
Putra, et al/Jurnal Ekonomi Syariah Teori dan Terapan Vol. 4 No. 12 Desember 2017: 952-967; PENGARUH PERKEMBANGAN BANK UMUM SYARIAH TERHADAP PERTUMBUHAN EKONOMI INDONESIA PERIODE 2010-2015

teknologi informasi yang belum mumpuni dikhawatirkan akan berdampak negatif terhadap kinerja perbankan syariah.

Inovasi produk juga diperlukan agar nantinya industri perbankan syariah Indonesia dapat bersaing secara global. Tidak dipungkiri memang persepsi masyarakat Indonesia terhadap perbankan syariah sampai saat ini pun masih belum tepat. Sistem ekonomi islam telah jelas, yaitu melarang mempraktikkan riba serta akumulasi kekayaan pada pihak tertentu secara tidak adil. Adanya perbedaan karakteristik produk bank syariah dan bank konvensional telah menciptakan keengganan dikarenakan nasabah akan kehilangan kesempatan mendapatkan penghasilan tetap berupa bunga dari simpanan.

Masyarakat umum yang beragama muslim pun khususnya di Indonesia, mayoritas belum memahami betul esensi dari perbankan syariah. Ini juga berkaitan dengan masih minimnya sumber daya manusia yang ahli dan profesional di bidang perbankan syariah.

Disamping itu, lembaga-lembaga akademik dan pelatihan di bidang ini sangat terbatas sehingga tenaga terdidik dan berpengalaman di bidang perbankan syariah masih sangat terbatas. Baik itu disisi pelaku perbankan syariah maupun tenaga pengawas perbankan syariah (Dewan Pengawas Syariah) masih sangat sedikit.

Pengembangan sumber daya manusia sangat penting dikarenakan perkembangan perbankan syariah sangat ditentukan pekerja yang terampil, memiliki kualitas manajemen yang baik, serta pengetahuan yang baik akan perbankan syariah.

Sementara itu pertumbuhan produk domestik bruto sektor perbankan juga meningkat pesat. Namun tidak dapat dipungkiri bahwa bank syariah masih memberikan kontribusi yang kecil bagi produk domestik bruto sektor perbankan. Sebagian besar masih didominasi oleh perbankan konvensional.

Dari data dapat diketahui bahwa market share perbankan syariah secara perlahan meningkat dari tahun 2010 hingga 2015. Pada tahun 2010 market share bank syariah tercatat $2,6 \%$, dimana pada saat itu masih berjumlah 6 bank umum syariah. hingga mencapai puncaknya pada tahun 2014 yang mencapai 4,9\%. Namun pada tahun 2015 ini terjadi penurunan ekonomi yang menyebabkan pangsa pasar perbankan syariah menurun. Ini juga disebabkan oleh kurangnya dukungan dari pemerintah yang mengakibatkan masyarakat tidak antusias lagi dalam menginvetasikan modalnya ke perbankan syariah.

Lalu pertumbuhan total aset perbankan syariah pada tahun 2010 yaitu 33,37\%. Hal ini termasuk tinggi mengingat baru ada 6 bank umum syariah. Selanjutnya pada tahun 2012 mencapai 47,55\%, pada tahun 2013 yaitu 34.06\%, hingga puncaknya pada tahun 2014 yang mencapai 4,9\%. Dari gambar pula dapat dilihat pertumbuhan pembiayaan bank umum syariah dimana pada tahun 2010 sebesar 
Putra, et al/Jurnal Ekonomi Syariah Teori dan Terapan Vol. 4 No. 12 Desember 2017: 952-967; PENGARUH PERKEMBANGAN BANK UMUM SYARIAH TERHADAP PERTUMBUHAN EKONOMI INDONESIA PERIODE 2010-2015

22,7\%. Lalu mencapai puncaknya pula pada tahun 2012 yang mencapai 50,53\%. Namun demikian pada tahun-tahun selanjutnya terjadi, sama halnya seperti yang terjadi pada marketshare, terjadi penurunan yang cukup signifikan.

\section{Perkembangan Variabel Penelitian}

\section{Total Aset 11 Bank Syariah}

Menunjukkan bahwa terjadi peningkatan yang signifikan dari total aset bank umum syariah tahun 2010-2015. Pada tahun 2010 total aset dari 11 bank umum syariah yaitu Rp.121.035 triliun rupiah. Pada tahun-tahun berikutnya terus mengalami peningkatan yang signifikan sehingga pada tahun 2011 mencapai Rp.168.130 triliun rupiah. Lalu pada tahun 2012 mencapai Rp212.772 triliun rupiah. Tahun selanjutnya yaitu tahun 2013 mencapai Rp.244.281 triliun rupiah. Tahun selanjutnya meningkat lagi menjadi Rp. 268.600 triliun rupiah. Dan data terakhir pada tahun 2015 mencapai Rp. 291.393 triliun rupiah.

\section{Total Pembiayaan 11 Bank Syariah}

Menunjukkan adanya peningkatan dari tahun ke tahun total pembiayaan 11 Bank Umum Syariah. Pada tahun 2010 total pembiayaan 11 Bank Umum Syariah mencapai Rp.22.057 triliun rupiah Tahun selanjutnya meningkat secara signifikan dari tahun ke tahun sehingga total pada tahun 2011 mencapai Rp.27.680 triliun rupiah. Lalu pada tahun 2012 mencapai Rp.59.010 triliun rupiah. Tahun selanjutnya yaitu tahun 2013 mencapai Rp.74.067 triliun rupiah. Tahun selanjutnya meningkat lagi menjadi Rp.78.546 triliun rupiah. Dan data terakhir pada tahun 2015 mencapai Rp.84.858 triliun rupiah.

\section{Produk Domestik Bruto sektor Perbankan}

Menunjukkan adanya peningkatan dari tahun ke tahun total Produk Domestik Bruto sektor perbankan. Pada tahun 2010 produk domestik bruto sektor perbankan mencapai Rp.90.167.000 triliun rupiah. Tahun selanjutnya meningkat secara signifikan dari tahun ke tahun sehingga total pada tahun 2011 mencapai Rp.96.393.000 triliun rupiah. Lalu pada tahun 2012 mencapai Rp104.391.000 triliun rupiah. Tahun selanjutnya yaitu tahun 2013 mencapai Rp113.983.000 triliun rupiah. Tahun selanjutnya meningkat lagi menjadi Rp119.372.000 triliun rupiah. Dan data terakhir pada tahun 2015 mencapai Rp.125.072.000 triliun rupiah.

\section{Uji Syarat Regresi}

\section{Uji Normalitas}

Model regresi yang baik adalah data yang terdsitribusi dengan normal. Hal ini dapat dilihat dari nilai probability yang nilainya lebih dari 5 persen. Dalam gambar menunjukkan bahwa nilai probabilitas lebih dari dari $a=5$ persen yaitu 0.259179 atau 25,9 persen. Oleh karena itu dapat disimpulkan bahwa tidak terdapat permasalahan normalitas. Lebih jelasnya dapat dilihat pada tabel dibawah :

\section{Gambar}

Uji Normalitas 


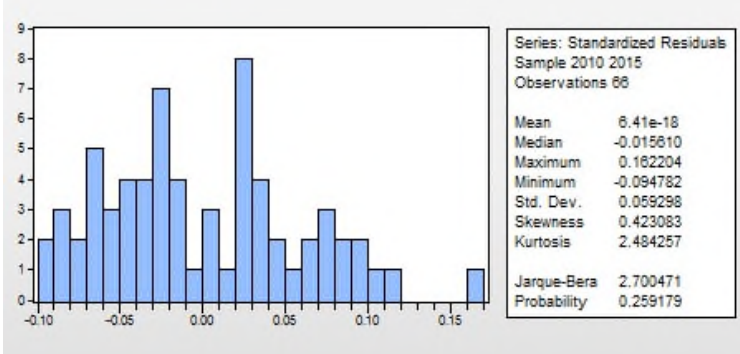

Uji Linieritas

Pengujian linieritas dilakukan untuk menguji apakah dalam suatu model regresi, variabel dependen atau keduanya mempunyai data yang linier atau tidak. Model regresi yang baik adalah data yang linier. Dari penghitungan yang dilakukan, hasilnya adalah 0,0000 . Maka dapat disimpulkan bahwa data yang diolah adalah linier. Ini berarti hasil penghitungan berada dibawah tingkat signifikansi. Untuk lebih jelasnya dapat dihitung sebagai berikut :

$\mathrm{LM}_{\text {hitung }}=\frac{11}{2(6-1)}\left\lceil\frac{0(0)^{2}}{0 \times 0}\right\rceil^{2}=0$

\section{Uji Chow}

Output yang dihasilkan dari uji chow adalah seperti tabel berikut :

\section{Tabel}

\section{Uji Redundant Fixed Effect}

\begin{tabular}{|l|l|l|l|}
\hline Effect Test & Statistics & d.f & Prob. \\
\hline Cross-sc.F & 4,716480 & $(10,53)$ & 0.0001 \\
\hline
\end{tabular}

Dari hasil diatas menunjukkan bahwa nilai probabilitas sebesar 0,0005 sehingga nilai probabilitas lebih kecil dari $a=5 \%$ dimana $\mathrm{H}_{0}$ diterima, artinya teknik estimasi yang baik digunakan dalam penelitian ini adalah model Fixed Effect Model (FEM). Karena yang terpilih adalah teknik estimasi dengan uji FEM maka tahap Uji Hausman yang digunakan untuk memilih antara metode FEM atau REM dalam penelitian perlu untuk dilakukan.

\section{Uji Hausmen}

Output yang dihasilkan dari uji hausmen adalah seperti tabel berikut :

\section{Tabel}

\section{Hausmen Test}

\begin{tabular}{|l|l|l|l|}
\hline Test_Summary & Chi-sq.Stat & Chi-sq d.f & Prob. \\
\hline Cross-sc.rndm & 47,164796 & 2 & 0.0000 \\
\hline
\end{tabular}

Dapat disimpulkan bahwa yang lebih tepat untuk digunakan adalah Fixed Effect Model dikarenakan pada nilai probabilitas (Prob.) cross-section random nilainya $<0.05$ maka model yang terpilih adalah Fixed Effect Model.

\section{Uji Langrange Multiplier}

Dari penghitungan yang dilakukan pada persamaan 3.1, didapat hasil yaitu 0,0000. Berikut adalah penjabaran nya:

LMhitung $=\frac{11}{2(6-1)}\left\lceil\frac{0(0)^{2}}{0 \times 0}\right\rceil^{2}=0$

Maka dari itu dapat disimpulkan bahwa yang lebih tepat digunakan adalah Fixed Effect Model dikarenakan hasil yang diperoleh dibawah tingkat signifikansi 0.05.

\section{Analisis Model Regresi}

Maka dari itu didapat lah model yang sesuai yakni Fixed Effect Model. Berikut adalah persamaan nya:

$Y_{i t}=\beta_{1}+\beta_{2} X_{2 i t}+\beta_{3} X_{3 i t}+\varepsilon_{i t}$.

$P D B_{i \dagger}=\beta_{1}+\beta_{2} T A B S_{2 i t}+\beta_{3} P_{B S S_{3 i t}}+\varepsilon_{i t}$

Dimana :

$\mathrm{PDB}_{i \dagger} \quad=$ PDB sektor Perbankan Nasional

$\beta_{1}, \beta_{2}, \beta_{3}=$ Koefisien Regresi

TABS $_{2 i t}=$ Total Aset Bank Umum Syariah 
Putra, et al/Jurnal Ekonomi Syariah Teori dan Terapan Vol. 4 No. 12 Desember 2017: 952-967; PENGARUH PERKEMBANGAN BANK UMUM SYARIAH TERHADAP PERTUMBUHAN EKONOMI INDONESIA PERIODE 2010-2015

PBS 3 it $\quad=$ Total Pembiayaan Bank Syariah

Hasil Estimasi Regresi Data Panel

\section{Tabel}

\section{Fixed Effect Model}

\begin{tabular}{|c|c|c|c|c|}
\hline $\begin{array}{l}\text { Dependent Variable: } \\
\text { Method: Panel Least S } \\
\text { Date: } 01 / 23 / 17 \text { Time: } \\
\text { Sample: } 20102015 \\
\text { Periods included: } 6 \\
\text { Cross-sections includ } \\
\text { Total panel (balanced) }\end{array}$ & $\begin{array}{l}(\mathrm{PDB}) \\
\text { ares } \\
27\end{array}$ & & & \\
\hline Variable & Coefficient & Std. Error & t-Statistic & Prob. \\
\hline LOG(TOTALASET) & 0.134691 & 0.033832 & 3.981237 & 0.0002 \\
\hline LOG(PEMBIAYAAN) & 0.030030 & 0.011926 & 2,517974 & 0.0149 \\
\hline $\mathrm{C}$ & 36.66575 & 0.379862 & 96.52385 & 0.0000 \\
\hline & Effects Spe & cification & & \\
\hline Cross-section fixed (d & my variables & & & \\
\hline R-squared & 0.772934 & Mean depen & ent var & 39.21635 \\
\hline Adjusted R-squared & 0.721523 & S.D. depend & atvar & 0.117076 \\
\hline S.E. of regression & 0.061782 & Akaike info ca & erion & $-2,555839$ \\
\hline Sum squared resid & 0.202301 & Schwarz crite & & -2.124544 \\
\hline Log likelihood & 97.34269 & Hannan-Quir & criter. & $-2,385414$ \\
\hline F-statistic & 15.03439 & Durbin-Wats & n stat & 0.799870 \\
\hline Prob(F-statistic) & 0.000000 & & & \\
\hline
\end{tabular}

Tabel 4.6 diatas, menunjukkan hasil estimasi dengan metode Fixed Effects Model (FEM), hasilnya menunjukkan bahwa model ini signifikan dalam uji $F$ (koefisien simultan) dengan tingkat kesalahan mendekati $0 \%$. Kinerja model tersebut juga cukup baik, yaitu dengan nilai dari $\mathrm{R}^{2}$ (koefisien determinasi) adalah sebesar $77,29 \%$ dan nilai Adjusted $\mathrm{R}^{2}$ (koefisien determinasi adjusted) adalah sebesar $72,15 \%$.

\section{Uji Hipotesis Secara Simultan}

Uji F-statistik pada penelitian ini menunjukkan nilai probabilitas kesalahan 0,000000 dimana lebih kecil dari tingkat kepercayaan sebesar 0,05 atau 5\%, bahkan tingkat kesalahannya $0 \%$ maka $\mathrm{H}_{0}$ ditolak dan menerima $H_{1}$. Hasil yang dapat disimpulkan yaitu bahwa variabel bebas yang dimaksudkan dalam model penelitian, yaitu jumlah total aset bank umum syariah dan total pembiayaan bank umum syariah secara simultan memiliki pengaruh yang signifikan terhadap variabel terikat yaitu produk domestik bruto sektor perbankan di Indonesia tahun 2010-2015.

Uji Hipotesis Secara Parsial

\begin{tabular}{|c|c|c|}
\hline Variabel & Prob. t-stat & Signifikansi \\
\hline Total Aset & 0,0002 & 0,05 \\
\hline Pembiayaan & 0,0149 & 0,05 \\
\hline
\end{tabular}

Dari tabel tersebut dapat disimpulkan bahwa :

1. Koefisien variabel Total Aset Bank Umum Syariah mempunyai nilai probabilitas t-hitung sebesar 0,0002. Angka ini menunjukkan nilai probabilitas t-hitung kurang dari level of significance $(a=0,05)$, sehingga $H_{0}$ ditolak dan $H_{1}$ diterima yang berarti kondisi Total Aset Bank Umum Syariah secara parsial berpengaruh positif dan signifikan terhadap Produk Domestik Bruto sektor perbankan di Indonesia tahun 20102015.

2. Koefisien variabel Total Pembiayaan Bank Umum Syariah mempunyai nilai probabilitas t-hitung sebesar 0,0149. Angka ini menunjukkan nilai probabilitas t-hitung kurang dari level of significance $(a=0,05)$, sehingga sehingga $\mathrm{H}_{0}$ ditolak dan $\mathrm{H}_{1}$ diterima yang berarti kondisi Total Pembiayaan Bank Umum syariah secara parsial berpengaruh positif dan signifikan terhadap Produk Domestik Bruto sektor perbankan di Indonesia tahun 2010-2015.

\section{Uji R² (R-squared)}

Pada hasil regresi data panel diperoleh koefisien determinasi $\left(R^{2}\right)$ yang 
Putra, et al/Jurnal Ekonomi Syariah Teori dan Terapan Vol. 4 No. 12 Desember 2017: 952-967; PENGARUH PERKEMBANGAN BANK UMUM SYARIAH TERHADAP PERTUMBUHAN EKONOMI INDONESIA PERIODE 2010-2015

menunjukkan kemampuan variasi variabel bebas (independent variable) secara bersama-sama dalam menjelaskan variabel terikat (dependent variable).

Angka $\mathrm{R}^{2}$ yang diperoleh lumayan tinggi, yaitu sebesar 0,772934 atau sebesar $77,29 \%$. Semakin mendekati satu, maka semakin kuat variasi variabel bebas (independent variable) dalam menerangkan variabel terikat (dependent variable), akan tetapi jika mendekati 0 maka semakin lemah variasi variabel bebas (independent variable) dalam menerangkan variabel terikat (dependent variable).

Variabel terikat (dependent variable) yaitu produk domestik bruto sektor perbankan di Indonesia tahun 20102015 dapat dijelaskan oleh variasi variabel bebas (independent variable) yaitu total aset bank umum syariah, dan total pembiayaan bank umum syariah sebesar 77,29 \% sedangkan sisanya sebesar 22,71 \% dapat dijelaskan oleh variabel-variabel pendukung lainnya di luar model penelitian (error term).

\section{PEMBAHASAN}

1. Hubungan Total Aset Bank Umum Syariah dengan Produk Domestik Bruto sektor perbankan

Berdasarkan probability total aset memiliki pengaruh yang signifikan terhadap produk domestik bruto sektor perbankan. Arah koefisien positif, artinya bahwa variabel total aset bank umum syariah menunjukkan hubungan positif (searah) secara simultan terhadap variabel produk domestik bruto perbankan, yakni setiap kenaikan total aset bank umum syariah sebesar 1 satuan, maka produk domestik bruto sektor perbankan akan naik sebesar 0,134691 dengan asumsi variabel lain dianggap tetap.

Perlu diperhatikan bahwa saat ini perbankan syariah memegang peranan penting dalam tumbuhnya perekonomian Indonesia. Bank Syariah terbukti tahan banting dalam menghadapi krisis global. Meskipun berpengaruh nya tidak sebesar perbankan konvensional. Namun ini cukup menunjukkan kemajuan yang signifikan dibandingkan tahun-tahun sebelumnya.

2. Hubungan Total Pembiayaan Bank Umum Syariah dengan Produk Domestik Bruto sektor perbankan

Berdasarkan probability total pembiayaan memiliki pengaruh yang signifikan terhadap produk domestik bruto sektor perbankan. Arah koefisien positif, artinya bahwa variabel total aset bank umum syariah menunjukkan hubungan positif (searah) secara simultan terhadap variabel produk domestik bruto perbankan, Koefisien regresi Total Pembiayaan perbankan syariah terhadap Produk Domestik Bruto perbankan adalah sebesar 0,030030 dengan tingkat probabilitas 0,0149 dan signifikan pada level $a=5 \%$. Nilai koefisien variabel total pembiayaan perbankan syariah menunjukkan hubungan negatif (tidak searah) terhadap variabel produk domestik bruto sektor perbankan, yakni 
Putra, et al/Jurnal Ekonomi Syariah Teori dan Terapan Vol. 4 No. 12 Desember 2017: 952-967; PENGARUH PERKEMBANGAN BANK UMUM SYARIAH TERHADAP PERTUMBUHAN EKONOMI INDONESIA PERIODE 2010-2015

setiap kenaikan total pembiayaan bank umum syariah sebesar 1 persen, maka produk domestik bruto sektor perbankan akan naik sebesar 0,030030 dengan asumsi variabel lain dianggap tetap, namun kenaikan variabel ini dianggap tidak memiliki akibat yang signifikan.

\section{ANALISA HASIL PENELITIAN}

Hasil koefisien determinasi $\left(R^{2}\right)$ yang bernilai positif yaitu sebesar 0.772934 atau sebesar 77,29\%, hal ini menunjukkan bahwa variabel terikat dalam penelitian ini berupa produk domestik bruto sektor perbankan mampu dijelaskan oleh variasi variabel bebas yang digunakan dalam model penelitian yaitu total aset bank umum syariah, dan total pembiayaan bank umum syariah sebesar 77,29\%. Angka koefisien determinasi yang ditunjukkan dalam hasil pengolahan data ini lumayan tinggi, hal ini menunjukkan bahwa ketiga variabel bebas lumayan akurat untuk menjelaskan variabel terikat yang ada.

Variabel-variabel pendukung lain yang tidak dimasukkan dalam model atau berada di luar model penelitian (error term) kemungkinan dapat dijelaskan oleh variabel jumlah perusahaan yang relevan dengan penelitian yang pernah dilakukan Haqiai Rafsanjani dan Raditya Sukmana (2013), hasil penelitiannya membuktikan bahwa total kredit perbankan konvensional, total simpanan bank konvensional, total aset bank konvensional, dan total simpanan bank syariah juga berpengaruh terhadap pertumbuhan ekonomi yang dalam hal ini digunakan variabel PDB sektor perbankan. Dalam hal ini, pembiayaan dalam negeri yang diberikan oleh sektor perbankan syariah telah ditemukan kontribusi pada pertumbuhan ekonomi Indonesia.

Berdasarkan pada perhitungan hasil regresi model panel dalam penelitian yang dilakukan, maka dapat dianalisis secara simultan bahwa variabel bebas berupa total aset bank umum syariah, dan total pembiayaan bank umum syariah mempunyai pengaruh yang positif atau signifikan terhadap variabel terikat yaitu produk domestik bruto sektor perbankan di Indonesia tahun 2010-2015, kedua variabel bebas ini secara simultan mampu memberikan pengaruh yang positif atau signifikan terhadap perkembangan produk domestik bruto sektor perbankan. Didukung dengan nilai probabiitas uji $\mathrm{F}$ (koefisien simultan) yang menunjukkan angka 0,0000 pada level of significance $(a=5 \%)$ dimana lebih kecil dari tingkat kepercayaan sebesar 0,05 bahkan tingkat kesalahannya mendekati 0\%, menjadikan ketiga variabel ini secara bersama-sama memiliki pengaruh yang kuat terhadap kondisi perkembangan jumlah pekerja di perbankan syariah.

Namun hanya variabel bebas total aset bank umum syariah yang secara parsial juga memiliki pengaruh yang positif atau signifikan terhadap variabel terikat. Sedangkan variabel total pembiayaan bank umum syariah tidak memiliki pengaruh secara parsial terhadap variabel terikat. Perhitungan suatu estimasi 
model akan menghasilkan parameter koefisien variabel bebas yang bertanda positif ataupu negatif. Perbedaan tanda tersebut akan menimbulkan makna secara matematis yang berbeda-beda pula. Jika parameter koefisien regresi bertanda positif, maka dapat diartikan bahwa setiap perubahan pada variabel bebas akan menyebabkan perubahan pada variabel terikat yang searah dengan perubahan variabel bebas, jika parameter koefisien regresi bertanda negatif, maka dapat diartikan bahwa setiap perubahan pada variabel bebas akan menyebabkan perubahan pada variabel terikat yang berlawanan arah dengan perubahan variabel bebas.

Kedua variabel bebas dalam penelitian ini mempunyai koefisien yang bernilai positif yang berarti bahwa variabelvariabel tersebut secara simultan mempunyai pengaruh positif atau searah terhadap variabel produk domestik bruto sektor perbankan di Indonesia tahun 20102015. Setiap terjadi perubahan pada variabel bebas akan menyebabkan perubahan pada variabel terikat yang searah dengan perubahan variabe bebas. Setiap terjadi kenaikan pada tiaptiap variabel bebas maka variabel terikatpun juga akan meningkat sebesar koefisien regresinya.

Sebagaimana yang dijelaskan diatas maka bagaimanapun harus diusahakan bahwa bagaimanapun usaha-usaha yang kita lakukan harus dilandaskan pada syariah. Maka dari itu diharapkan kedepannya akan semakin banyak yang beralih ke bank syariah, utamanya umat muslim itu sendiri. Prinsip-prinsip syariah yang dijadikan pedoman sepert tidak menggunakan produk-produk yang bersifat bunga dan spekulasi

\section{SIMPULAN}

1. Seluruh variabel bebas yaitu total aset bank umum syariah, dan total pembiayaan bank umum syariah berpengaruh secara simultan terhadap produk domestik bruto sektor perbankan di Indonesia tahun 20102015.

2. Variabel total aset bank umum syariah berpengaruh secara parsial terhadap produk domestik bruto sektor perbankan di Indonesia. Sedangkan variabel bebas total pembiayaan bank umum syariah secara parsial berpengaruh positif dan signifikan terhadap produk domestik bruto sektor perbankan di Indonesia periode 20102015.

\section{DAFTAR PUSTAKA}

Antonio, Muhammad Syafi'i. 2001. Bank Syariah Dari Teori Ke Praktek. Jakarta: Gema Insani bekerjasama dengan Tazkia Cendekia.

Bank Indonesia 2010. Statistik Perbankan Syariah Indonesia. Berbagai Edisi. Jakarta: Direktorat Perbankan Syariah Indonesia.

2011. Statistik Perbankan Syariah Indonesia. Berbagai Edisi. Jakarta: Direktorat Perbankan Syariah Indonesia.

2012. Statistik Perbankan Syariah Indonesia. Berbagai Edisi. Jakarta: Direktorat Perbankan Syariah Indonesia.

2013. Statistik Perbankan Syariah Indonesia. Berbagai Edisi. Jakarta: Direktorat Perbankan Syariah 
Indonesia.

2014. Statistik Perbankan

Syariah Indonesia. Berbagai Edisi. Jakarta: Direktorat Perbankan Syariah Indonesia.

2015. Statistik Perbankan Syariah Indonesia. Berbagai Edisi. Jakarta: Direktorat Perbankan Syariah Indonesia.

Banoon dan Malik. 2007. Prediksi Pertumbuhan Perbankan Syariah di Indonesia tahun 2008. Surabaya: Universitas Kristen Petra.

Boediono. 1999. Teori Pertumbuhan Ekonomi. terjemahan. Yogyakarta: BPFE-UGM.

Gujarati, Damodar. (2007). Dasar-Dasar Ekonometrika. Erlangga, Jakarta.

Karim, Adiwarman. 2004. Bank Islam: Analisis Fiqih dan Kevangan. PT.Rajagrafindo Persada. Jakarta.

Karim, Adiwarman. 2008. Ekonomi Makro Islami Edisi Kedua, PT Raja Grafindo Persada, Jakarta.

Mankiw, N. Gregory. 2000. Teori Makro Ekonomi. terjemahan. Jakarta: Erlangga.

Sadono, Sukirno. 2006. Ekonomi Pembangunan Proses Masalah dan Dasar Kebijakan. Jakarta: Kencana.

Setiawan, Azis Budi. 2006. Perbankan Syariah: Challenge dan Opportunity Untuk Pengembangan di Indonesia. Jurnal Kordinat: Volume VIII no.1, April 2006.

Sirojuzilam. 2008. Ekonomi dan Perencanaan Regional, Medan; Penerbit Pustaka Bangsa.

Soemitra, Andri. 2009. Bank dan Lembaga Kevangan Syariah Jakarta: Kencana Pradana Media Group. 